\title{
Women Entrepreneurs Have Limited Chances to Lead Their New Businesses
}

\author{
Howard E. Aldrich (University of North Carolina at Chapel Hill)
}

KEYWORDS: Public Administration \& Government, Social Media \& Networks, Entrepreneurship, Management, Leadership, Family Business, Contracts, Women, Business Owners, Family businesses, Business for women.

Women who start new businesses with men have limited opportunities to move into leadership roles, according to a study we conducted at University of North Carolina at Chapel Hill; and when they co-found a business with their husbands, they have even fewer chances to be in charge.

The

study

(http://asr.sagepub.com/content/79/2/303.abstract) , published in the April 2014 issue of the American Sociological Review, comes on the heels of a recent debate about businesses with all-male boards of directors and adds to a growing body of knowledge that documents women's limited access to leadership roles in the business world.

"This work raises awareness of the conditions that limit women's access and also makes us aware of what might be done to increase the likelihood that women will attain positions of authority," says my colleague Tiantian Yang, a graduate student in the department of sociology in UNC's College of Arts and Sciences, who led the study.

Yang and I wanted to explain gender inequality in new businesses because previous research has mostly examined the issue in established organizations. Such firms often have well-established bureaucratic procedures for hiring and promotion, whereas startups must build systems and structures from scratch. Our study is one of the first to explore the emergence of gender roles in new businesses.

We used a nationally representative sample of 362 mixed-sex startup teams, with 880 entrepreneurs on those teams. It's important to note that our sample

includes small, everyday businesses that are still in the startup stages -- such as bakeries, gift shops, and building contractors. None of them have reached the growth potential of a Twitter or a Facebook.

Seventy percent of the mixed-sex teams that we studied are husband-wife teams.

"Our explanation for more pronounced gender inequality in spousal teams is that when husband and wife work together, they carry with them the cultural expectations for the male breadwinner and the female homemaker roles into the business setting," says Yang. "And the more children there are at home, the more it amplifies the expectation that the woman will also take on the role of leader of the household."

We found that gender inequality in entrepreneurial teams can be reduced when people adopt organizational templates, such as signing a formal operating agreement and developing a business plan in the early stages of the company's founding. These mechanisms help teams evaluate men's and women's competence more equitably and make "competence" more salient.

Our study revealed that men are 85 percent more likely than women to be in charge when team members have not signed a formal ownership agreement, but men and women have about the same chance to lead a team when that team has adopted such an agreement.

In our opinion, these formal operating agreements level the playing field for entrepreneurial women and the men in their organizations. One of the things we hope this will do is provoke a conversation, so that the next time a couple or a mixed-sex team starts talking about forming
Copyright ( 2014 The Authors. Entrepreneur \& Innovation Exchange is published at EIX.org. This is an open access article under the terms of the Creative Commons Attribution-NoDerivs License, which permits use and distribution in any medium, provided the original work is properly cited and no modifications or adaptations are made. View EIX.org Authorship Terms at https://eix.org/terms
FamilyBusiness 
a business, they can ask, "Who should be the boss? Who is better at this? Let's talk about the basis by which we'll decide that."

The Kauffman Foundation of Kansas City, Mo. supported our research.

\section{Read More:}

Advice, Best Practices and Inspiration for Women Entrepreneurs(https://familybusiness.org/women)

Additional search terms: women, feminism, female founders, women business owners, glass ceiling, sexual discrimination, bias, opportunity, challenges to women in business 